\title{
Refined oil prices with family cars
}

\author{
Aiqing Zhen,Cuxiao Huo,Chunqing Feng \\ Mathematics and Physics College, Dongying Teachers College, Shandong, China
}

\begin{abstract}
Nowadays, more and more cars have begun to enter into innumerable families; the family car has become a necessity for Chinese households who have certain purchasing power. However, the ups and downs of oil prices have brought some impact on people's automobile consumption activities. Therefore, after collecting the information of the oil price and family car consumer, carried on through in-depth analysis of the relevant data with reasonable relationship, and then developed a suitable for China's national conditions and finished oil pricing model, thereby the National Development and Reform Commission have proposed the suggestion for China's refined oil pricing mechanisms and promoting the healthy development of new energy vehicles with specific measures. For question 1, through the problem analysis and information access, combined with the past and current situation of the domestic refined oil prices, we analyze the following seven factors: international crude oil prices, China's annual crude oil imports, China's annual crude oil exports, crude oil output in China, China's annual GDP per capita, China's annual consumption of crude oil, the total annual energy consumption in China, all have influence on China's refined oil prices. By monadic linear regression analysis, annual average prices of domestic refined oil products have a certain correlation with the various influencing factors, and then by multiple linear regression way eventually concluded the final relationship between oil prices and the influence factors, which compared with the current price, and make reasonable evaluation model. Through the establishment of various influencing factors and function of time, and using the evaluation model for refined oil product price to make reasonable forecast. According to this model, in order to predict refined oil product price as $\$ 122.15$ per barrel in 2016. For question two, we basically sums up three key factor which influence the quantity of family vehicle: China's oil product prices, the annual GDP per capita, total road mileage. Through Excel to make the relationship curves of different quantity of family cars against influencing factors, and use Grey Forecasting method to forecast the quantity of family cars. And carries on the residual error test, it is used to conclude that the rationality of the model is highly. The number of private cars of the city of xi 'an is predicts that to 8.302 million vehicles by 2020. For question three, we discussed the relationship between international crude oil prices and domestic exports of crude oil export with domestic refined oil prices, through its multiple linear regressions to get the final pricing model. For question four, according to three previous established models, we proposed China's refined oil pricing mechanism proposal to the national development and Reform Commission: perfect price controls, deeper product market, and integration of resources consideration and environmental protection class tax types, adjust the consumption tax collection and Administration links, and improve the production cost accounting.
\end{abstract}

Key words:linear regression, multiple linear regressions, Excel, Grey Forecasting method, residual test

\section{Problem restatement}

With the rise of the automotive industry, cars become more and more people living necessities, but the fluctuation of oil prices has brought a considerable impact on cost of living. Select a certain city, collecting the actual data for the family car, influence factor of refined oil price (list down the sources), by following the establishment of mathematical models, and answer the questions.

1. Analyze the factors that affect the China refined oil price, establish a mathematical model, and forecast the China oil prices in 2016.

2. The mathematical model is given to the growth of the number of family cars and the prospects for the development of household cars in 2020 are predicted, indicating the impact of refined oil prices on household growth.

3. Analysis of foreign refined oil prices pricing factors, given a suitable refined oil pricing model for China's national conditions.

4. According to the model you have established, propose the proposal of China's refined oil pricing mechanism and promote specific measures for the development of new energy vehicles to the National Development and Reform Commission.

\section{Problem analysis}

Analysis of question one:

We have analyzed the following seven factors by data collection: international crude oil prices, China's annual crude oil imports, China's annual crude oil exports, China's annual crude oil production, China's
GDP per capita, China's annual crude oil consumption, China's total annual energy consumption, these all are the impact on China's refined oil prices which cannot be ignored. Through the analysis of the influencing factors of the China's refined oil price and its relevant data in recent years, the data are sorted and analyzed by matlab, and the mathematical model based on linear regression theory can be obtained. After the model is solved scientifically, initial China's refined oil prices can be forecasted.

Analysis of question two:

We take Xi'an City in Shaanxi Province as an example, its relevant data have been collected and summarized through the household car consumption situation of Xi'an city in the past 10 years, and the relevant factor which influence Xi'an family car consumption we have made the necessary analysis and synthesis, We basically summed up the impact of the results base on three key factors: China's refined oil prices, GDP per capita, and highway mileage. The prospect of the number of private cars in Xi'an in 2020 was forecasted by grey forecasting method.

Analysis of problem three:

Through the access to relevant information, further analysis of many foreign countries refined oil price pricing factors and pricing mechanism, as a basis for China's refined oil pricing research. Domestic oil prices are affected by a number of factors: international crude oil prices, China's annual crude oil imports, China's annual crude oil exports, China's annual crude oil production, China's GDP per capita, China's annual crude oil consumption, China's total annual energy consumption. In the case of full access to the literature, the 
international crude oil prices and China's crude oil exports accounted for a larger impact. Through the residual map, we find that these two factors are related to the domestic refined oil price, and use the multiple linear regressions to develop a model of refined oil for China. Analysis of question four:

According to the established model, propose the proposal of China's refined oil pricing mechanism and promote specific measures for the development of new energy vehicles to the National Development and Reform Commission, in order to achieve the ultimate goal of this issue study.

\section{Model hypothesis}

1. Assume that the data collected in the paper are true and reliable;

2. Do not consider the impact of war and natural disasters on crude oil prices;

3. Do not take into account the financial crisis that occurred since 2005;

4. Do not consider the impact of monopoly crude oil and other factors;

5. Assume that the models created in the paper are applicable to any one area;

6. Do not take into account the impact of government regulation on crude oil prices;

7. Exclude large changes in the world currency exchange rate since 2005;

8. Exclude the impact of the huge changes in the automotive industry in recent years;

9. Exclude the impact of non-locomotives and other modes of transport on the number of domestic cars;

10. To exclude the impact of government restriction and purchase restriction on the purchase of private vehicles by the public;

11. Exclude the impact of population size and structure in recent years; 12. Do not take into account the impact of fluctuations in the car prices on the consumption of family cars in Xi'an;

13. Do not take into account the government's macroeconomic regulation and control of domestic oil prices;

14. Does not consider the impact of China and international crude oil production on domestic oil prices;

15. Assume that the data used in the paper is accurate enough.

\section{Symbol Description}

Y ------- China refined oil price (USD / barrel)

X1 -------- International crude oil price (USD / barrel)

X2 ------- Annual Domestic crude oil production volume (ten thousand tons)

X3 -------- Annual China's crude oil export volume (ten thousand tons)

X4 ------- Annual China's crude oil imports volume (ten thousand tons)

X5 ------- Annual Domestic crude oil consumption volume (barrels)

X6 --------Annual Total energy consumption in China (10,000 tons of standard coal)

X7 ------- Annual China disposable income per capita (yuan)

X8 ------- Xi'an annual GDP (yuan)

$\mathrm{X} 9$------- highway mileage in Shaanxi Province $(\mathrm{km})$

$\mathrm{X} 10$------- number of private cars in Xi'an (ten thousand)

X11 ------- China's car ownership (ten thousand)

\section{The Establishment and Solution of Model}

Question one:

1.1 to explore the relationship between the main affecting factors and China's refined oil prices:

We learned from the information that the price of Chinese refined oil is often affected by many factors. It is assumed that the secondary factors are neglected and the main factors are considered, the analysis shows that the fluctuation of China's refined oil prices have a direct relationship with the international crude oil price X1, Annual Domestic crude oil production volume X2, Annual China's crude oil export volume X3, Annual China's crude oil imports volume X4, Annual Domestic crude oil consumption volume X5, Annual Total annual energy consumption of China X6, Annual China per capita disposable income X7.

A. The Relationship between International Crude Oil Price and China's refined oil prices

China's refined oil prices consist of market-oriented ingredients, and also government control components, which proportion of marketoriented components is largest, it is largely determined by the international crude oil prices, so the international crude oil prices have a larger influences on China's refined oil prices. 【1】

International Crude Oil Price (USD / barrel) $\quad 53.39 \quad 64.29$

$\begin{array}{llllll}71.12 & 96.99 & 61.76 & 77.01 & 94.89 & 94.12\end{array}$

98.00

$\begin{array}{llll}\text { Refined oil price (USD / barrel) } & 58.40 & 70.12 & 77.79\end{array}$

$\begin{array}{llllll}104.82 & 65.22 & 82.70 & 100.79 & 100.66 & 102.35\end{array}$

Using matlab to do linear regression analysis [2]

Correlation coefficient: $\mathrm{r} 12=0.9956, \mathrm{y}=1.0314 * \mathrm{X} 1+3.2184$

B. The relationship between China's annual oil production and China's refined oil prices

China's annual production of crude oil increased year by year, reflecting the market demand for China is increasing year by year, this phenomenon will affect the China refined oil price, so it is necessary to explore the relationship between China's annual oil production

【3】 and China's refined oil prices.

China's annual oil production (10,000 tons) $\quad 18083.8918367 .59$

18665.6918972 .8218948 .9620301 .4020364 .6020747 .80 20812.87

China's refined oil prices (USD / barrel) $\quad 58.40 \quad 70.12$

$\begin{array}{llllll}77.79 & 104.82 & 65.22 & 82.70 & 100.79 & 100.66\end{array}$

102.35

Using matlab to do linear regression analysis:

Correlation coefficient: $\mathrm{r} 22=0.5591, \quad \mathrm{y}=0.012466 * X 2-158$

C. The relationship between China's crude oil export volume and China's refined oil price

Due to the implementation of the concept of sustainable development in China, the annual export volume of crude oil decreased year by year. China's crude oil exports [3] indirectly affect the price of refined oil, but it also affected by refined oil prices, so the two closely linked, as shown in the figure.

China's crude oil exports (10,000 tons) $806.69 \quad 633.72 \quad 382.92$

$\begin{array}{llllll}373.34 & 518.40 & 304.22 & 252.20 & 243.00 & 162.00\end{array}$

China refined oil price (USD / barrel) $\quad 58.40 \quad 70.12 \quad 77.79$

$\begin{array}{llllll}104.82 & 65.22 & 82.70 & 100.79 & 100.66 & 102.35\end{array}$

Using matlab to do linear regression analysis:

Correlation coefficient: $\mathrm{r} 32=0.7441, \quad \mathrm{y}=-0.074202 * X 3+115.07$ 
D. Relationship between China's Crude Oil Import and China's refined oil prices

With the development of the economy, in order to meet the needs of the domestic market, China's annual imports of crude oil increased year by year. China's crude oil imports [3] directly determines the price of refined oil, but it also affected by refined oil prices, so the two closely linked, inseparable.

China's crude oil imports (10,000 tons) 12708.3214518 .0316317 .55 17889.3020378 .9323931 .1425254 .9227102 .0028195 .00

$\begin{array}{llll}\text { China refined oil price (USD / barrel) } & 58.40 & 70.12 & 77.79\end{array}$ $\begin{array}{llllll}104.82 & 65.22 & 82.70 & 100.79 & 100.66 & 102.35\end{array}$

Using matlab to do linear regression analysis:

Correlation coefficient: $\mathrm{r} 42=0.5118, \mathrm{y}=0.0022574 * \mathrm{X} 4+38.035$

E. The relationship between the annual consumption of domestic crude oil and China's refined oil price

Domestic crude oil consumption and China's refined oil prices affect each other, their relationship is close, lower China's refined oil prices will stimulate domestic consumption of crude oil, and increase annual consumption of crude oil, while the higher price of Chinese refined oil will restrain the domestic crude oil consumption to some extent. Therefore, the domestic annual consumption of crude oil [3] and China's refined oil prices are closely linked.

Domestic crude oil annual consumption (barrel) 29985.5232251 .90 34600.3136488 .7838809 .5043868 .3345367 .3247606 .80 48845.87

$\begin{array}{llll}\text { China refined oil price (USD / barrel) } & 58.40 & 70.12 & 77.79\end{array}$ $\begin{array}{llllll}104.82 & 65.22 & 82.70 & 100.79 & 100.66 & 102.35\end{array}$

Using matlab to do linear regression analysis:

Correlation coefficient: $\mathrm{r} 52=0.5319, \mathrm{y}=0.0018885 * \mathrm{X} 5+9.6792$

F. The Relationship between Annual Total energy consumption in China and China's Oil Product Price

China's refined oil consumption is an important part of China's total energy consumption, and plays an important role in China's economic development. When energy demand is in contradiction with the actual situation, the price of energy will inevitably produce fluctuation. Therefore, China's total annual energy consumption [3] and refined oil prices have a very close relationship.

Annual Total energy consumption in China $(10,000$ tons of standard coal) $\quad \begin{array}{lllllll}235997 & 258676 & 280508 & 291448 & 306647 & 34939\end{array}$ $348002 \quad 361732 \quad 375000$

China refined oil price (USD / barrel $58.40 \quad 70.12 \quad 77.79$ $\begin{array}{llllll}104.82 & 65.22 & 82.70 & 100.79 & 100.66 & 102.35\end{array}$

Using matlab to do linear regression analysis:

Correlation coefficient: $\mathrm{r} 62=0.5765, \mathrm{y}=0.00028747 * \mathrm{X} 6-4.1286$

G. The relationship between annual China's disposable income per capita and China's refined oil prices

China's refined oil prices are indirectly affected by the annual disposable income per capita, energy consumption is an indispensable part of national consumption; and is the motive force to maintain the steady and healthy growth of the national economy. As a representative of the energy consumption pattern, the oil price naturally has an inseparable relationship with the annual income per capita.

annual China's disposable income per capita (yuan) $\quad 10493.0$ $\begin{array}{llllll}11759.5 & 13785.8 & 15780.8 & 17174.7 & 19109.4 & 21809.8\end{array}$ 24564.726955 .1

$\begin{array}{llll}\text { China refined oil price (USD / barrel) } & 58.40 & 70.12 & 77.79\end{array}$ $\begin{array}{llllll}104.82 & 65.22 & 82.70 & 100.79 & 100.66 & 102.35\end{array}$

Using matlab to do linear regression analysis:

Correlation coefficient: $\mathrm{r} 72=0.5646, \mathrm{y}=0.002371 * \mathrm{X} 7+42.233$

1.2 The impact of seven factors on refined oil prices:

$\begin{array}{lllllll}\text { Year } & 2005 & 2006 & 2007 & 2008 & 2009 & 2010\end{array}$

$20112012 \quad 2013$

China refined oil price (USD / barrel) $\quad 58.40 \quad 70.12 \quad 77.79$ $\begin{array}{llllll}104.82 & 65.22 & 82.70 & 100.79 & 100.66 & 102.35\end{array}$

International crude oil price (USD / barrel) $\quad 53.39 \quad 64.29$ $\begin{array}{llllll}71.12 & 96.99 & 61.76 & 77.01 & 94.89 & 94.12\end{array}$ 98.00

Annual domestic crude oil production (10,000 tons) 18083.89 18367.5918665 .6918972 .8218948 .9620301 .4020364 .60 20747.8020812 .87

Annual China's crude oil exports (10,000 tons) $\quad 806.69 \quad 633.72$ $\begin{array}{llllll}382.92 & 373.34 & 518.40 & 304.22 & 252.20 & 243.00\end{array}$ 162.00

Annual China's crude oil imports (10,000 tons) 12708.3214518 .03 16317.5517889 .3020378 .9323931 .1425254 .9227102 .00 28195.00

Annual domestic crude oil consumption (barrel) 29985.5232251 .90 34600.3136488 .7838809 .5043868 .3345367 .3247606 .80 48845.87

Annual Total energy consumption in China (10,000 tons of standard coal) $\quad \begin{array}{lllllll}235997 & 258676 & 280508 & 291448 & 306647 & 349390\end{array}$ $348002 \quad 361732 \quad 375000$

Annual China disposable income per capita (yuan) $\quad 10493.0$ $\begin{array}{llllll}11759.5 & 13785.8 & 15780.8 & 17174.7 & 19109.4 & 21809.8\end{array}$ $24564.7 \quad 26955.1$

Using matlab to achieve multiple linear regression analysis and calculation

????R2 $=0.9994 \quad \mathrm{~F}=249.0376 \quad \mathrm{P}=0.0488<0.05$

Average price of Chinese refined oil:

$\mathrm{Y}=-4.2351+1.0593 * \mathrm{X} 1-0.0366 * \mathrm{X} 2+0.0301 * \mathrm{X} 3-0.0381 *$

$\mathrm{X} 4+0.0387 * \mathrm{X} 5-0.0001 * \mathrm{X} 6-0.0004 * \mathrm{X} 7$

Factor regression equation correlation coefficient $\mathrm{r} 2$

International crude oil price $\mathrm{y}=1.0314 \mathrm{X} 1+3.2184 \quad 0.9956$

Annual domestic crude oil production $\mathrm{y}=0.012466 \quad \mathrm{X} 2-158$ 0.5591

Annual China's crude oil exports $\quad \mathrm{y}=-0.074202 \quad \mathrm{X} 3+115.07$ 0.7441

Annual China's crude oil imports $\quad \mathrm{y}=0.0022574 \quad \mathrm{X} 4+38.035$ 


$$
0.5118
$$

Annual domestic crude oil consumptiony $=0.0018885$ 0.5319

Annual China Energy Total Consumption

$4.1286 \quad 0.5765$

Annual China disposable income per capita

$y=0.00028747 \quad X 6-$

$\mathrm{X} 5+9.6792$

$\mathrm{X} 7+42.233$ 0.5646

1.3 Evaluation of model results:

Year $2005 \quad 2006 \quad 2007$

$20112012 \quad 2013$

$2008 \quad 2009 \quad 2010$

$\begin{array}{llllll}77.79 & 104.82 & 65.22 & 82.70 & 100.79 & 100.66\end{array}$

102.35

Calculation of China's refined oil price (USD / barrel) )

$\begin{array}{lllll}68.13 & 76.23 & 103.42 & 64.22 & 82.26\end{array}$

$100.21 \quad 103.53$

With matlab on the actual average annual oil price and the calculation of the average annual oil price comparison

According to the graph, the model calculated by the China refined oil price is very close to the actual China refined oil price, so the mathematical model established above is basically reasonable. Therefore, we can use the established mathematic model to predict the price of China refined oil in other years reasonably and efficiently.

1.4 China's refined oil price forecast in 2016

The relationship between the main factors which influencing the China refined oil price and time:

Influencing factors monadic linear regression equation

relationship between the international crude oil price and time $\mathrm{X} 1=4.9248 \mathrm{t}-9814.9$

relationship between the annual domestic crude oil production and time $\quad \mathrm{X} 2=379.72 \mathrm{t}-743380$

relationship between the annual China's crude oil exports and time $\mathrm{X} 3=-68.025 \mathrm{t}+137070$

relationship between the annual China's crude oil imports and time X4=2060.3t-4118300

relationship between the annual domestic crude oil consumption and time $\quad$ X $5=2507 \mathrm{t}-4996800$

relationship between the annual China Energy Total Consumption and time $\quad \mathrm{X} 6=17228 \mathrm{t}-34301000$

relationship between the annual China disposable income per capita and time $\mathrm{X} 7=2060.7 \mathrm{t}-4122000$

The model of linear regression can be seen from the value of each parameter above. Next, this model is used to predict the price of Chinese refined oil 2016.

Substituting $t=2016$ to get:

$\begin{array}{llllllr}x & x & x & x & x & x & x \\ 113.50 & 22135.52 & -68.40 & & 35264.80 & 57312.00 & 430648.00 \\ & 32371.20 & & \end{array}$

Obtain y $(\mathrm{t}=2016)=-4.2351+1.0593 * \mathrm{x}-0.0366 * \mathrm{x}+0.0301 * \mathrm{x}-$ $0.0381 * \mathrm{x}+0.0387 * \mathrm{x}-0.0001 * \mathrm{x}-0.0004 * \mathrm{x}=122.15$ (USD / barrel)
2.1 Analysis of data in Excel

Through the past ten years of the household car consumption in Xi'an, the collation and compilation of data and the relevant factors influencing the consumption situation of the family car in Xi'an, the necessary analysis and synthesis, we basically summarize the three key factors influencing the results: China refined oil price y, Xi'an Annual GDP X8, Shaanxi Provincial highway mileage X9, number of private cars X10 in Xi'an City. Therefore, the list of relevant data for the three key factors established by this model is as follows:

Year China refined oil price (USD/barrel) (approximate) Xi'an GDP (billion) highway mileage in Shaanxi Province

$(10,000 \mathrm{~km}) \quad$ Number of private cars in Xi'an $(10,000)$ (Da Qin net)

$\begin{array}{lllll}2006 & 5485 & 1450.0 & 11.33 & 42.8 \\ 2007 & 5748 & 1737.1 & 12.13 & 50.8 \\ 2008 & 6680 & 2000.0 & 13.10 & 59.6 \\ 2009 & 7070 & 2719.1 & 14.41 & 75.5 \\ 2010 & 8260 & 3241.5 & 14.75 & 97.7 \\ 2011 & 9130 & 3688.8 & 15.20 & 117.5 \\ 2012 & 9800 & 4369.4 & 16.14 & 140.0 \\ 2013 & 9500 & 4884.1 & 16.52 & 161.5 \\ 2014 & 9300 & 5474.0 & - & 239.3\end{array}$

The impact of various factors on the number of private cars

The Relationship between the GDP Per Capita and the Number of Private Cars

\begin{tabular}{|c|c|c|c|c|c|}
\hline 2003 & 2004 & 2005 & 2006 & 2007 & 2008 \\
\hline 2009 & 2010 & 2011 & & & \\
\hline \multicolumn{2}{|c|}{ GDP Per Capita (yuan) } & 10542 & 12336 & 14185 & 16500 \\
\hline 20169 & 23708 & 25608 & 30015 & 35063 & \\
\hline Growth rate $\%$ & 17.02 & 17.02 & 15.00 & 16.32 & 22.24 \\
\hline 17.54 & 8.01 & 17.21 & 16.82 & & \\
\hline \multicolumn{3}{|c|}{ Number of private cars (ten thousand) } & 1070.20 & 1481.66 & 1848.07 \\
\hline 2333.32 & 2876.2 & 3501.39 & 4574.91 & 5938.71 & 7326.79 \\
\hline
\end{tabular}

GDP Per capita and private car quantity

According to the above chart, the growth of automobiles is exponentially correlated with GDP growth, and the index of road mileage is relevant. So we can predict the number of home cars by using grey forecasting method.

2.2 Grey Forecasting method for the number of family cars [4]

1) The selected data is from 2003 to $2011 \mathrm{Xi}^{\prime}$ an Private car Number [5], the time series initial value is: Set the original series is

$\mathrm{x}=[\mathrm{x}(1), \mathrm{x}(2), \ldots, \mathrm{x}(9)]=$

$[42.8,50.8,59.6,75.5,97.7,117.5,140.0,161.5,239.3]$

2) The process of generating accumulation sequences to accumulate the data of the series is called the cumulative generation process.

Let $\mathrm{x}$ ? 1 ? $(\mathrm{k})=\mathrm{x}(\mathrm{i}), \mathrm{k}=1,2, \ldots, \mathrm{n}$,

The obtained new series $x=[x(1), x(2), \ldots x(n)]$ is the 1 cumulative number of sequence $x$ generation series. There are $\mathrm{x}=[42.8,93.6,153.2,228.7,326.4,443.9,583 \cdot 9,745.4,984.7]$

3) Calculate the ratio

Level ratio: $\sigma(\mathrm{k})=, \mathrm{k}=1,2, \ldots, \mathrm{n}$ 。

Question 2: 
$\sigma(2)=0.457$

$\sigma(3)=0.611$

$\sigma(4)=0.670$

$\sigma(5)=0.700$

$\sigma(6)=0.735$

$\sigma(7)=0.783$

$\sigma(8)=0.757$

?If all the ratio fall within the coverable range $X=(e, e)$, the data $\mathrm{x}$ ?o?can establish the GM $(1,1)$ model and can be predicted in grey. From $\mathrm{n}=8$ can be covered with cover interval $\mathrm{X}=(-0.80,1.22)$, calculate the ratio to meet the requirements. ?

4) Establish GM $(1,1)$ model

$+\operatorname{ax}(\mathrm{k})=\mathrm{u}$ where $\mathrm{a}$ is the development of grey number, $\mathrm{u}$ as the endogenous control grey number.

The solution is $x(k)=(x(1)-) e+$ formula (1)

Let $\theta=(\mathrm{a}, \mathrm{u})$ be the parameter vector to be evaluated and use the least squares method

$\theta=(\mathrm{BB}) \mathrm{BY}$, where $\mathrm{Y}$ is the column vector $\mathrm{Y}[\mathrm{x}$ ?o?(2) , $\mathrm{x} ? \mathrm{o} ?(3), \ldots, \mathrm{x} ? \mathrm{o} ?(8)]$

Where $Y=[50.8,59.6,75.5,97.7,117.5,140.0,161.5,239.3]$

$\mathrm{B}$ of the construction data matrix $\quad \mathrm{B}=$

Calculated by matlab

$\mathrm{a}=-0.1663$

$\mathrm{u}=61.4654$;

Substituting the formula (1) for the formula

$\mathrm{x}(\mathrm{k})=(369.8+42.8) \mathrm{e}-369.8$ formula (2)

$\mathrm{x}(\mathrm{k}+1)=412.4 \mathrm{e}-369.8$ formula (3)

use the serial down

$\mathrm{x}(\mathrm{k})=\mathrm{x}(\mathrm{k}+1)-\mathrm{x}(\mathrm{k})$

We draw the curve of the number of private cars in Xi'an with the growth of the year by Matlab software; it shows roughly in the form of exponential growth

The following data are obtained by graph calculation

$\mathrm{x}(1)=42.8$ the number of private cars in $\mathrm{Xi}^{\prime}$ an in year 2006 by the model is $x(1)=42.8$

$\mathrm{x}(2)=89.5$ the number of private cars in Xi'an in year 2007 by the model is 2$)=46.7$

$x(3)=147.8$ the number of private cars in Xi'an in year 2008 by the model is $x(3)=58.3$

$x(4)=220.6$ the number of private cars in Xi'an in year 2009 by the model is $\mathrm{x}(4)=72.8$

$x(5)=311.4$ the number of private cars in Xi'an in year 2010 by the model is $\mathrm{x}(5)=90.8$

$x(6)=424.0$ the number of private cars in $\mathrm{Xi}^{\prime}$ an in year 2011 by the model is $x(6)=113.3$

$x(7)=566.0$ the number of private cars in Xi'an in year 2012 by the model is $x(7)=141.3$

$\mathrm{x}(8)=742.4$ the number of private cars in $\mathrm{Xi}^{\prime}$ an in year 2013 by the model is $x(8)=176.4$

$x(9)=962.4$ the number of private cars in Xi'an in year 2014 by the model is $x(9)=220.0$
5) To test the establishment of the grey model, the steps are as follows:

(1) Calculate the residual $\mathrm{e}(\mathrm{t})$ and the relative error $\mathrm{q}(\mathrm{x})$ between $\mathrm{xand}$ $\mathrm{x}$ ?o?

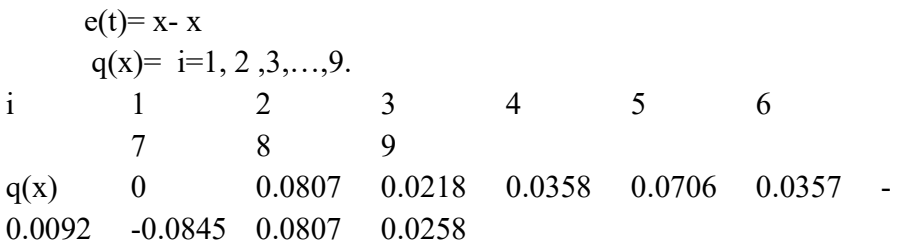

With reference to the table to know the relative error of $\mathrm{q}(\mathrm{x})<0.05$, the grey model accuracy as level two, ao the degree of fitting is relatively good.

Grey model accuracy test comparison table

Level relative error $\mathrm{q}$ variance ratio $\mathrm{C}$ small error probability

Level I $<0.01<0.35>0.95$

Level II $<0.05<0.50<0.80$

Level III $<0.10<0.65<0.70$

Level IV $>0.20>0.80<0.60$

So we can use Formula 3 to predict the number of private cars in Xi'an in 2020 .

$\mathrm{x}(10)=1236.6$ the number of private cars in Xi'an in year 2015 by the model is $x(10)=274.5$

$x(11)=1579.2$ the number of private cars in Xi'an in year 2016 by the model $x(11)=342.6$

$x(12)=2006.6$ the number of private cars in Xi'an in year 2017 by the model $x(12)=427.4$

$x(13)=2539.9$ the number of private cars in Xi'an in year 2018 by the model $\mathrm{x}(13)=533.3$

$x(14)=3205.3$ the number of private cars in Xi'an in year 2019 by the model $\mathrm{x}(14)=665.4$

$x(15)=4035.5$ the number of private cars in Xi'an in year 2020 by the model $\mathrm{x}(15)=830.2$

The calculation of the number of private cars in Xi'an by 2020 was predicted by the MATLAB software is 8.302 million.

Analysis of the effect of oil price on the number of household cars. From the Excel chart we found that 2006-2014 China's refined oil prices rose steadily in the first six years, while the number of private cars in Xi'an was also increasing. In 2012-2014, China's refined oil prices declined slightly, because of the downward adjustment of international oil prices, but this has little impact on the purchase of cars in Xi'an city residents, the number of private cars in Xi'an still has a significant boost. Because lower grade cars are cheaper to buy, the price rises undoubtedly have certain sensitivity to the prospective users of such vehicles, the rise in oil prices will lead to the slowdown in sales of such cars; but for high-grade car prospective users, the rise in oil prices is not a big obstacle to car purchases. It can be seen that the fundamental factors influencing the automobile consumption are the sustained development of the economy, the gradual improvement of the residents ' purchasing ability, the price of refined oil is a continuous trend, it is only to some extent to the residents of car consumption has an impact.

Question 3:

At present, the global oil pricing mainly has three forms: one is 
marketization pricing model, the developed countries represented by the United States are basically market pricing; The second is the government pricing model, mainly the oil-rich countries, through the high government subsidies to implement the low oil price policy; Thirdly, intermediate roads, both market-oriented and governmentregulated components, our country belongs to this model.

Taking petrol prices as an example, , the average annual retail price of gasoline in USA for year 2013 was 2.29 times of year 2003, and the average annual gasoline retail price in England for year 2013 was 1.75 times of year 2000; the average annual retail price of gasoline in Germany for year 2013 was 1.43 times of yeat 2003, and the average annual retail price of gasoline in Japan for year 2013 years was 1.38 times of year 2003; The retail price of gasoline and diesel in Korea for year 2013 was 1.48 times of year 2003, and the average annual retail price of gasoline in Taiwan for year 2013 was 1.61 times of year 2003.

For example, the pricing of refined oil produced by American refineries at domestic and abroad is entirely determined by the market. There are two representative oil spot markets in the United States: the Gulf of Mexico, including the Texas region and the east Coast oil consumption area. The price of oil in both markets is determined by supply and demand, and fluctuates with the volatility of oil prices in international markets. The retail price of each gas station in the United States is not the same, even if the same company's gas station prices will be different, gas station managers will usually be based on the lot, service content and quality, sales, peripheral gas stations, and other gas stations to compete with the extent of profits and other conditions to set prices.

Belgium does not produce oil, but the reason why Belgian governments, businesses and consumers who are not alarmed at high prices of fuel price is its unique fuel pricing mechanism. In Belgium, the retail price of fuel is comprised of four parts: the first is the cost of imports, the second is the dealer's profit; third is the consumption tax; and fourth is value-added tax (VAT). Among them, consumption tax is relatively fixed, while VAT While the VAT is the sum of the first three and then multiplied by a fixed ratio. Since 1975, the Belgium government has signed a contract with the Belgium Petroleum Association, which comprised from the oil importers to stabilize the supply and price of oil. For example, the first paragraph of the new contract signed between the two party on October 2006 clearly stipulates that the Belgium economy will take all administrative and managerial means to ensure the supply and stability of the domestic oil market.

In addition, tax burden is not the only main factor that lead to the gap of retail price of oil in different countries or regions, but also to adjust the price to encourage consumption. The United States is a typical low-tax country, which has played a part in encouraging consumption, while Japan, South Korea and most European countries have adopted a high oil tax policy to control oil consumption. 【6】

According to the analysis and induction of the existing data, the pricing factors affecting domestic refined oil prices include domestic GPI, international crude oil prices, China's crude oil imports, China's annual crude exports, domestic GDP growth, domestic crude oil production, domestic crude oil costs, China's car holdings. All these factors contributed large or small impact on domestic oil prices. However, after checking the data through Excel on the above seven factors and the relative analysis of domestic refined oil prices, international crude oil price and China crude oil annual export volume correlation coefficient is 0.9956 and 0.7441 respectively, and the domestic product average price of oil is highly relevant. Therefore, the influence of other factors on the price of Chinese refined oil could be neglect. The relationship between international crude oil price and annual crude oil exports as a result of variable, explores international crude oil price $\mathrm{X}$ and China crude oil annual export volume $\mathrm{X}$ and China refined oil price $\mathrm{y}$ through 'mat lab' multivariate linear regression analysis:

Relevancy analysis table:

Factor

Year Annual domestic crude oil production

(tons) ?International crude oil price (USD / barrel) Annual

domestic crude oil production (10,000 tons) Annual China's

crude oil exports (10,000 tons) Annual China's crude oil

imports (10,000 tons) Annual Total energy consumption in

China (10,000 tons of standard coal) Annual China disposable

income per capita (yuan)

$\begin{array}{lllll}2005 & 29985.5253 .39 & 58.40 & 806.69 & 12708.32 \\ 235997\end{array}$

10493.0

$\begin{array}{lllll}2006 & 32251.9064 .29 & 70.12 & 633.72 & 14518.03258676\end{array}$

11759.5

$\begin{array}{lllll}2007 & 34600.3171 .12 & 77.79 & 382.92 & 16317.55280508\end{array}$

13785.8

$\begin{array}{lllll}2008 & 36488.7896 .99 & 104.82 & 373.34 & 17889.30 \\ 291448\end{array}$

15780.8

$2009 \quad 38809.5061 .76 \quad 65.22 \quad 518.40 \quad 20378.93306647$

17174.7

$2010 \quad 43868.3377 .01 \quad 82.70 \quad 304.22 \quad 23931.14349390$

19109.4

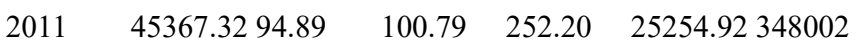

21809.8

$2012 \quad 47606.8094 .12 \quad 100.66 \quad 243.00 \quad 27102.00361732$

24564.7

$2013 \quad 48845.8798 .00 \quad 102.35 \quad 162.00 \quad 28195.00375000$

26955.1

With the average price of domestic refined oil $\quad 0.5319 \quad 0.9956$ $\begin{array}{lllll}0.5591 & 0.7441 & 0.5118 & 0.5765 & 0.5645\end{array}$

The following result was obtained using 'mat lab' for its linear regression:

$$
\begin{aligned}
& \mathrm{y}=-2.4415+1.0794 \mathrm{x}+0.0046 \mathrm{x} \\
& \mathrm{R}=0.9963 \quad \mathrm{~F}=804.6822 \quad \mathrm{P}=0.0000 \quad \mathrm{~S}=0.0392
\end{aligned}
$$

The residual analysis was done on the data that shows high correlation. The residual distribution is as below:

According to the residual distribution above, from the distance of data residuals to 0 points, the residual intervals are 0 points, the regression model is accurately reflect the characteristics of the original data. Therefore the final mathematical model is expressed as:

$$
y=-2.4415+1.0794 x+0.0046 x \text {. }
$$

Question 4:

4.1 Suggestions for China National development and Reformation commission on refined oil pricing mechanism:

The international crude oil price is the main concern on the pricing of domestic refined oil. However, it is inappropriate to underestimate the actual situation of domestic oil supply and demand. Therefore, the domestic refined oil in the process of pricing cannot be ignored but to be integrated.

1. The method to improve the pricing control. First of all, China's 
refined oil prices cannot and should not be entirely influenced by the fluctuation of international oil prices, the status of oil consumption and the future of uncertainty in international energy supply has led to the intervention and control of oil prices in the country. Therefore, we must design a specific method of oil price control early, formulate comprehensive and detailed control plans, and consider the affordability of consumers, production enterprises and government finances, to avoid the passive situation and error decision caused by the sudden arrival of high oil prices.

2. The integration of taxation on the resources and environmental protection. We should strengthen the environmental protection on refined oil resources and excise taxes, the integration or coordination of special tax exemption on oil enterprises, in a forward-looking study, early design of the feasibility of the plan, so to ensure the next step on smoothing the reformation on refined oil prices and tax system, promoting energy-saving emission reduction and environmental protection, and conducive to safeguarding social equality.

3. Adjust the management and collection of tax on oil consumption. In the future, the collection of refined oil consumption tax should gradually transition to the wholesale level, which allows oil consumption tax to regulate and play a better role. On the other hand, that can also promote China's tax collection and management level.

4. Improve the calculation of cost of production. Due to the monopoly position of the domestic oil market, the price of refined oil is difficult to be reasonable and competitive, and the government guidance on pricing is unavoidable in the coming future, which is only the cost and profit pricing method. Due to the important position of oil price in the society, the relevant ministries should set up a joint working group to calculate the production cost of the industry periodically, to prevent the occurrence of financial statements by the relevant enterprises due to their own interests.

4.2 Measures to promote the development of renewable energy vehicles:

1. The Government should offer adequate grants and subsidies to encourage households to buy renewable energy vehicles. With the improvement of living standards, many families are ready to purchase of a slightly higher price renewable energy car, but they are lack of the concept of changes and adaptation. This is the time that the government's responsibility to take practical action to encourage consumers to try new energy vehicles, and then guide consumers to establish energy conservation awareness In the international community. For example, since 1st January 2008, the France government provide rewards and punishment to the vehicle owner according to the purchase of new vehicles $\mathrm{CO} 2$ emissions, to encourage the purchase of low-emission environmentally friendly models.

2. The government invests in domestic automotive enterprises or related research units focusing on the development and improvement of new energy vehicles. The government's strong support for any one of the automotive manufacturers is a tremendous momentum to gain great strides. This embodies the government's emphasis on energy conservation and environmental protection, and is the most direct and effective measure to promote the development of new energy vehicles. For example, 2007, the German government had put the key technology of electric vehicles, which are lithium-ion batteries as a critical project in the "high-tech strategy". June 2008, the German government and Volkswagen, as well as energy suppliers, EON and other industrial giants jointly announced a hybrid automotive development plan. At the beginning of 2009, 500 million euros in the 50 billion-euro stimulus package adopted by the German Government was used to develop electric vehicles, of which 170 million euros were used to support the development of batteries powered for electric vehicles.

3. The Government should try to regulate its subordinate units to reduce oil exploitation and focus on the development and use of other clean energy sources. Other clean energy sources include solar energy, hydrogen energy, bio-energy, ethanol, and so on. Many developed countries have attached great importance to clean energy and have achieved the desired results. April 2007, the Bush administration unveiled standards to encourage the mixing of renewable fuels in American motor vehicle fuels. Based on this criterion, in the year 2007, the requirement of U.S. automotive energy consumption must be $4 \%$ of renewable fuels, such as ethanol which extract from grains, roughly 4.7 billion gallons. This standard value will rise annually, reaching 7.5 billion gallons by 2012 , while the government has also formulated preferential policies for the production of fuel ethanol.

\section{Evaluation and improvement of the model}

For the Model 1, the model is cumbersome, and the linear regression thought used in the research of relationship between the research results and the influencing factors can make the problem more appropriately solved. But for the neglected other factors, this kind of thinking is still difficult to take into account, so cannot be exhaustive, still have some defects.

For model 2, grey forecasting method is innovative, can effectively solve the problems which need to predict. However, this method is limited to forecasting and cannot accurately explain the link between the price of refined oil and the consumption of automobiles.

For the model 3, this model fitting the topic requirements, processing is simpler, data processing accuracy is higher, but the thought is more similar with the model one.

\section{REFERENCES}

[1]. 'Data briefing: Since 1970, the international crude oil price movements and events' China Economic Net

http://intl.ce.cn/specials/zxxx/201307/31/t20130731_24622321.shtml

[2]. Fu Li 'Gray System Theory and Its Application' Science and Technology Literature Publishing House 1992

[3]. National Bureau of Statistics of the People's Republic of China www.stats.gov.cn

[4]. Zhuo Jinwu 'MATLAB in the application of mathematical modeling' Beijing University of Aeronautics and Astronautics Press 2004-1

[5]. Daqin network 'Xi'an car holdings of high-speed growth' http://xian.qq.com/a/20110524/000287.htm

[6]. Bi Dedong 'foreign refined oil pricing mechanism analysis' Baidu library Http://wenku.baidu.com/view/635cc6492b160b4e767fcf0d.html 